\title{
Alcohol screening, brief intervention, and stepped care with older alcohol users
}

\author{
Ruth McGovern ${ }^{1 *}$, Simon Coulton ${ }^{2}$, Jude Watson ${ }^{3}$, Martin Bland ${ }^{3}$, Colin Drummond ${ }^{4}$, Eileen Kaner ${ }^{1}$, \\ Christine Godfrey ${ }^{3}$, Alan Hassey ${ }^{5}$, Dorothy Newbury-Birch ${ }^{1}$ \\ From International Network on Brief Interventions for Alcohol Problems (INEBRIA) Meeting 2011 \\ Boston, MA, USA. 21-23 September 2011
}

The Alcohol Needs Assessment Project estimated that $20 \%$ of people aged $\geq 55$ years consume alcohol at levels hazardous to their health, which is associated with a wide range of physical, psychological, and social problems, including coronary heart disease, hypertension, stroke, liver disease, and increased risk of a range of cancers. The Alcohol-Evaluating Stepped Care for Older Populations (AESOPS) research study is a randomized controlled trial looking at the effectiveness and cost-effectiveness of an opportunistic screening, brief intervention, and stepped care framework for older hazardous alcohol users in primary care compared with minimal intervention. Opportunistic screening of patients aged $\geq 55$ years was conducted in 53 primary health care practices from eight areas across England. Patients who screened positive for an alcohol use disorder (AUD) were randomly allocated to one of two intervention conditions: brief structured advice (minimal intervention) or stepped care. Approximately 78,260 screening questionnaires were distributed, and 21,524 (27.5\%) were returned. Seven-and-a-half percent of respondents screened positive for AUD. Of eligible patients, $51.3 \%$ were randomized to stepped care, most (99.6\%) of whom received step one (brief lifestyle intervention); $55.1 \%$ received step two (brief motivational intervention), and $10.2 \%$ were referred to step three (specialist alcohol treatment). Results to date are discussed.

\footnotetext{
Author details

'Institute of Health and Society, Newcastle University, Newcastle upon Tyne, UK. ${ }^{2}$ Center for Health Service Studies, University of Kent, Canterbury, UK. ${ }^{3}$ Department of Health Sciences, University of York, Heslington, York, UK. ${ }^{4}$ National Addiction Center, Institute of Psychiatry, King's College London, London, UK. ${ }^{5}$ Fisher Medical Center, Skipton, UK.
}

'Institute of Health and Society, Newcastle University, Newcastle upon Tyne, UK

Full list of author information is available at the end of the article
Published: 9 October 2012

doi:10.1186/1940-0640-7-S1-A27

Cite this article as: McGovern et al: Alcohol screening, brief intervention, and stepped care with older alcohol users. Addiction Science \& Clinical Practice 2012 7(Suppl 1):A27.
Submit your next manuscript to BioMed Central and take full advantage of:

- Convenient online submission

- Thorough peer review

- No space constraints or color figure charges

- Immediate publication on acceptance

- Inclusion in PubMed, CAS, Scopus and Google Scholar

- Research which is freely available for redistribution

\section{() Biomed Central}

C Biomed Central

(c) 2012 McGovern et al; licensee BioMed Central Ltd. This is an Open Access article distributed under the terms of the Creative Commons Attribution License (http://creativecommons.org/licenses/by/2.0), which permits unrestricted use, distribution, and reproduction in any medium, provided the original work is properly cited. 